\title{
An Experimental Study of the Effects of Chloride Ions on the Corrosion Performance of Polymer Coated Rebar in Concrete Pavement
}

\author{
Khoa Tan Nguyen ${ }^{1}$, Jaehong Lee ${ }^{2}$, Kangsu Lee ${ }^{3}$ and Namshik Ahn** \\ ${ }^{1}$ Master Candidate, Free Form Architecture Institute, Department of Architectural Engineering, Sejong University, South Korea \\ ${ }^{2}$ Professor, Free Form Architecture Institute, Department of Architectural Engineering, Sejong University, South Korea \\ ${ }^{3}$ Korean Register of Shipping, Green \& Industrial Technology Center, South Korea \\ ${ }^{4}$ Associate Professor, Free Form Architecture Institute, Department of Architectural Engineering, Sejong University, South Korea
}

\begin{abstract}
Construction materials have been greatly improved in recent years and reinforced concrete is no exception. However, corrosion inside reinforced concrete continues to be a primary problem in the construction field. This paper considers the corrosion rate of special kinds of steel inside reinforced concrete pavement. Corrosion is caused by chloride ions present in the deicing salts used to melt snow on pavement. These chloride ions cause endosmosis in the structure of steel and eventually destroy it. In order to prevent such corrosion, layers have been created to protect the steel. The authors use the polarization resistance method to check the ability of such barriers. The variables of this experimental study were four kinds of steel: black rebar, stainless steel 304 clad rebar, galvanized coated rebar A and galvanized coated rebar B. According to the test result, black steel corroded much more than the others with the presence of salt. Although the galvanized A rebar corroded more slowly than the galvanized $\mathrm{B}$ rebar in $\mathrm{Ca}(\mathrm{OH})_{2}$ plus the threshold amount $\mathrm{NaCl}$, the corroding resistance of the galvanized $\mathrm{B}$ rebar was better in the presence of $3.5 \% \mathrm{NaCl}$. However, of the four kinds of steel, the pure stainless steel 304 clad rebar proved to be the best in terms of corrosion resistance.
\end{abstract}

Keywords: corrosion rate; coated rebar; polarization resistance; polymer coating

\section{Introduction}

Corrosion of the reinforcement bar (rebar) is the main cause of damage and early failure of reinforced concrete structures. The reinforcement in these structures provides constructional security. Steel embedded in good quality concrete is protected by the high alkalinity of pore water, which in the presence of oxygen, passivates the steel. The loss of alkalinity due to the carbonation of the concrete and the penetration of chloride ions to steel can destroy the passive film.

Corrosion of reinforcement in concrete has been a matter of great concern in recent years due to an increase in the consumption of deicing salts on highways. The problem has been traced to corrosion of reinforcement caused by chlorides present in deicing salts. Despite its disastrous effect on reinforcement, salt is still used extensively to keep roads clear of snow

*Contact Author: Namshik Ahn, Associate Professor, Free Form Architecture Institute, Department of Architectural Engineering, Sejong University, South Korea

Tel: +82-10-9108-0696 Fax: +82-2-3408-3833

E-mail: nsahn@sejong.ac.kr

(Received April 16, 2011 ; accepted January 23, 2012) in harsh winters.

Therefore in order to control corrosion, polymercoated reinforcing steel is used in concrete as an alternative to black steel reinforcement. However, corrosion spalls began to appear in the substructure of bridges built with polymer-coated rebars. It is evident that using polymer-coated rebars does not always prevent corrosion in aggressive environments. Therefore, research was needed to evaluate the corrosion performance of other coatings and claddings such as pure stainless steel rebars and galvanized rebars.

\section{Materials and Test Methods \\ 2.1 Materials}

There are four kinds of steel utilized in this research: black rebar, stainless steel 304 clad rebar, galvanized coated rebar A and galvanized coated rebar B. The galvanized A was bent after it was coated, and the galvanized B was coated after it was bent. The diameter of both is $12.7 \mathrm{~mm}$.

As shown in Figs.1. and 2., a rebar (short for reinforcing bar), also known as reinforcement steel, is a common steel bar, and is commonly used as a 
tensioning device in reinforced concrete and reinforced masonry structures by holding the concrete in compression. It is usually formed from carbon steel, and is given ridges for better mechanical anchoring into the concrete ${ }^{1)}$.

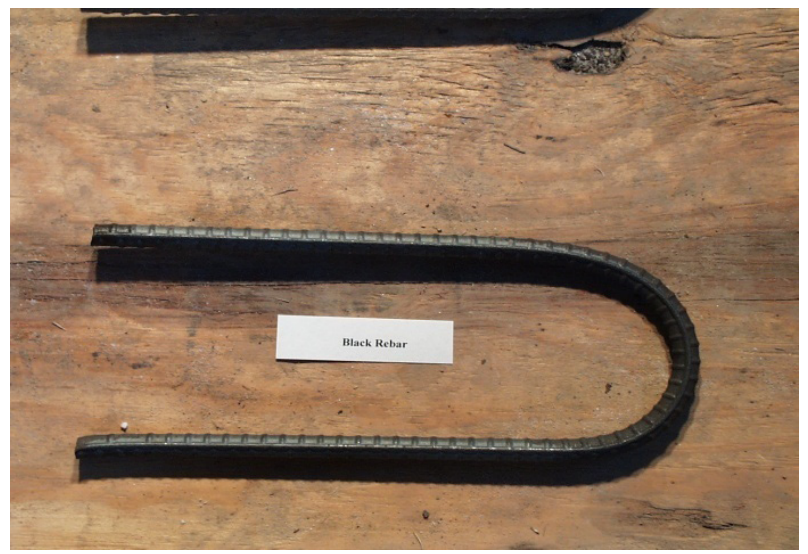

Fig.1. Black Rebar

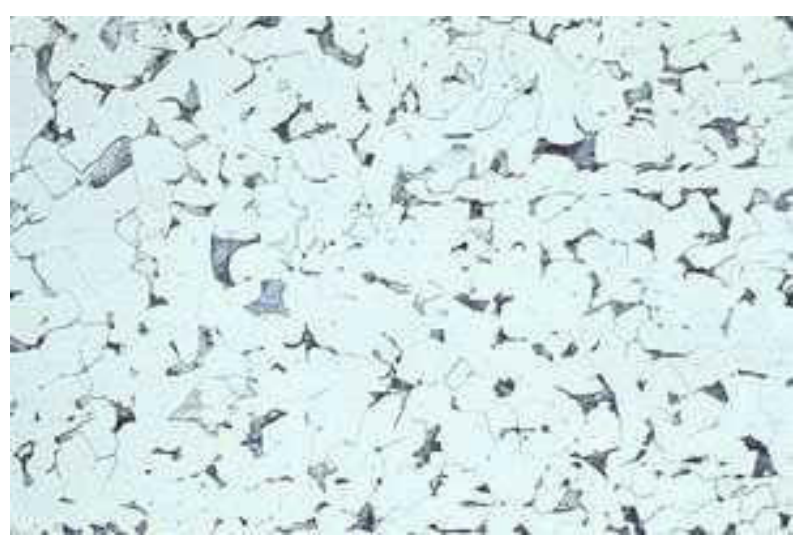

Fig.2. SEM Photograph of Black Rebar ${ }^{2)}$

A hot-dip galvanized rebar, as shown in Figs.3., 4. and 5., is simply bare steel coated with zinc. In order to coat black reinforcing steel with zinc, it is first cleaned by dipping it in a series of solutions that remove dirt, oil, oxides, and other contaminants from the surface. Zinc is applied to the clean steel by immersing it into a bath of liquid zinc heated to $830^{\circ} \mathrm{F}\left(430^{\circ} \mathrm{C}\right)$. The liquid zinc metallurgically reacts with the iron producing a tightly adherent coating. The steel is then set aside to cool prior to inspecting it for conformity to the appropriate specifications ${ }^{3)}$.

In metallurgy stainless steel, also known as inox steel or inox from the French "inoxydable", is defined as a steel alloy with a minimum of $10.5 \%$ or $11 \%{ }^{5)}$ chromium content by mass. Stainless steel does not stain, corrode, or rust as easily as ordinary steel, but it is not stain-proof ${ }^{6}$.

It is also called corrosion-resistant steel or CRES when the alloy type and grade are not detailed, particularly in the aviation industry. There are different grades and surface finishes of stainless steel to suit the

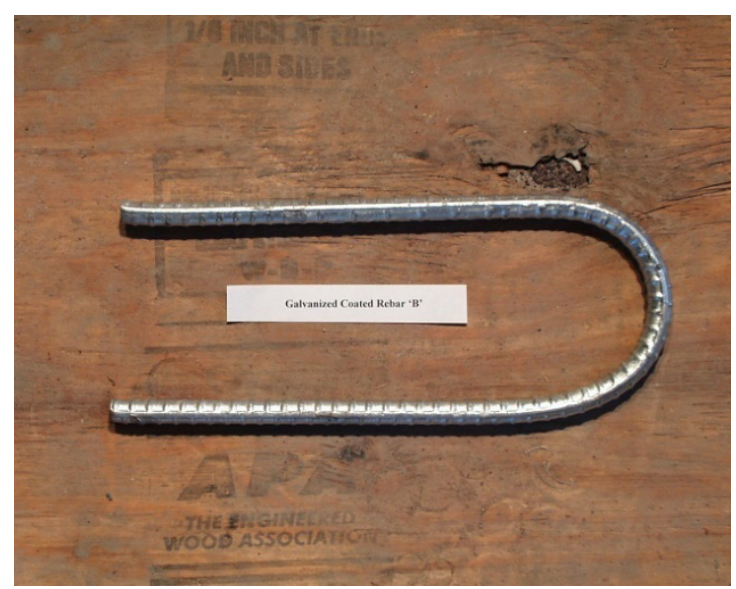

Fig.3. Galvanized B Coated Rebar

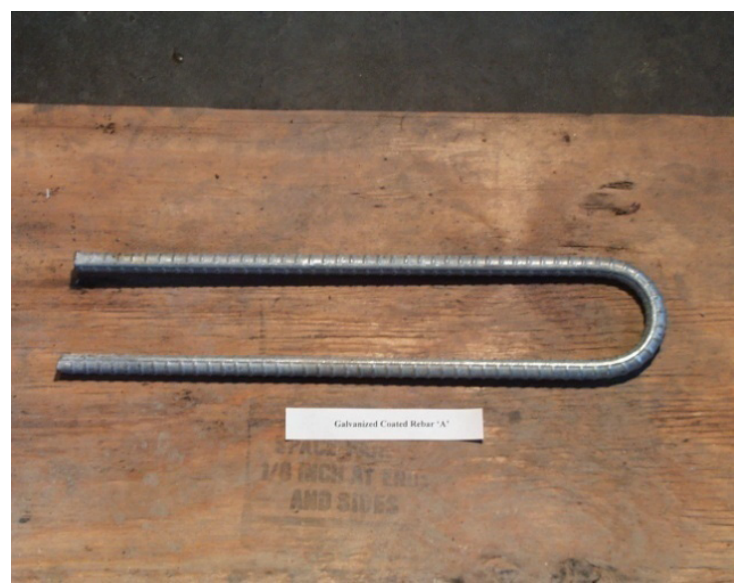

Fig.4. Galvanized A Coated Rebar

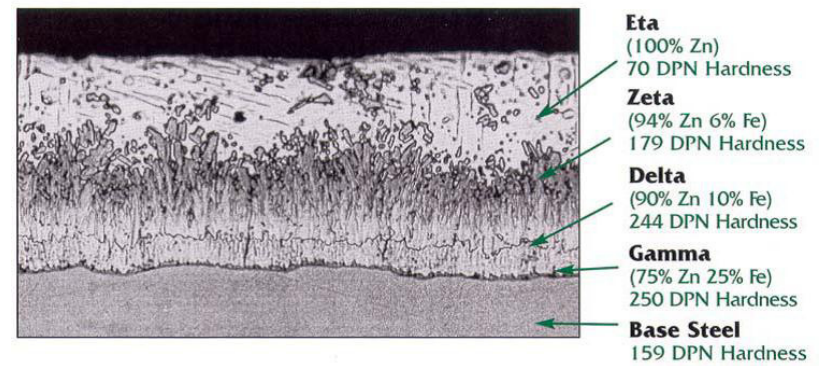

Fig.5. SEM Photograph of Galvanized Rebar ${ }^{4)}$

environment to which the material will be subjected in its lifetime. Stainless steel is used where both the properties of steel and resistance to corrosion are required.

Stainless steel, as shown in Figs.6. and 7., differs from carbon steel by the amount of chromium present. Carbon steel rusts when exposed to air or moisture. This iron oxide film (the rust) is active and accelerates corrosion by forming more iron oxide. Stainless steels contain sufficient chromium to form a passive film of chromium oxide, which prevents further surface corrosion and blocks corrosion from spreading into the internal structure of the metal ${ }^{7)}$. 


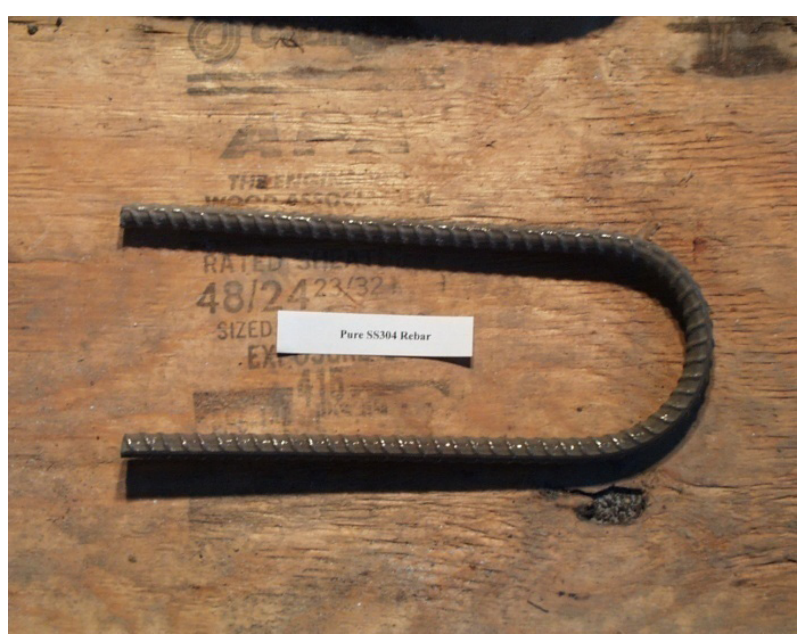

Fig.6. Stainless Steel 304 Clad Rebar

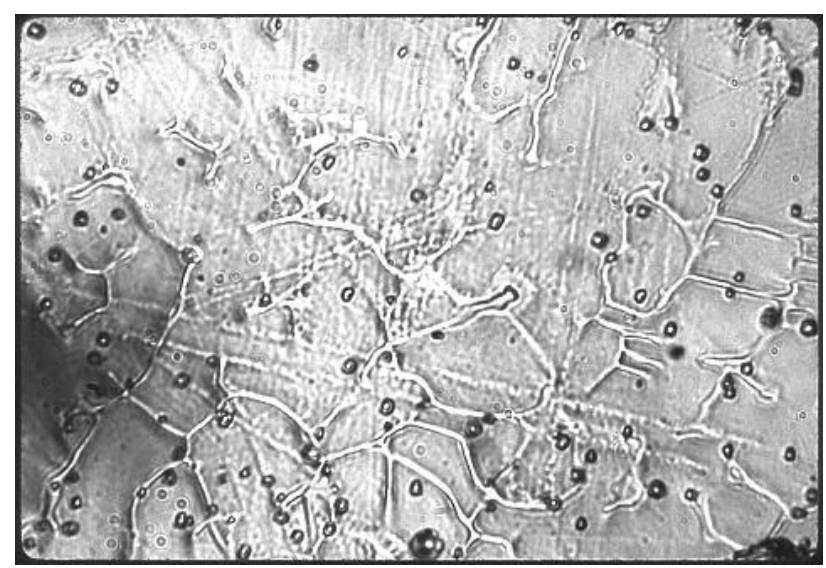

Fig.7. SEM Photograph of Stainless Steel ${ }^{8)}$

Four kinds of steel were used by the authors for this study, as indicated in Table 1:

Table 1. Types of Reinforcement Bars

\begin{tabular}{lll}
\hline Rebar type & Color & Experimental code \\
\hline 1. Black rebar & Black & BLK4 \\
\hline $\begin{array}{l}\text { 2. Stainless steel 304 } \\
\text { clad rebar }\end{array}$ & Silver-gray & SS304 \\
\hline $\begin{array}{l}\text { 3. Galvanized coated } \\
\text { rebar (A) }\end{array}$ & Silver & GALV(A) \\
\hline $\begin{array}{l}\text { 4. Galvanized coated } \\
\text { rebar (B) }\end{array}$ & Silver-gray & GALV(B) \\
\hline
\end{tabular}

\subsection{Test methods}

In earlier studies, researchers used Finite Element Methods or Boundary Element Methods. These methods were based on computers to evaluate the corrosion rate and combined knowledge of the mechanics of deformable bodies and corrosion rate. $3 \mathrm{D}$ or 2D models and the boundary conditions: concrete surface, dry conditions, wet conditions,... were set up $^{9)}$. Researchers must have good knowledge of computers and must be painstakingly thorough. When it is necessary to evaluate the corrosion rate in the short term, different methods must be used.
The method used in this research is the polarization resistance method. It has certain advantages over other methods, as usually only a few minutes are required to determine the corrosion rate. Polarization methods are non-destructive and may be used numerous times to measure consecutive corrosion rates on the same electrode.

The formula is from the Stern-Geary Equation ${ }^{10)}$ :

$$
I_{\text {corr }}=\frac{\beta_{a} \beta_{c}}{2.3 R_{p}\left(\beta_{a}+\beta_{c}\right)}
$$

where

$\mathrm{I}_{\text {corr }}$ : the corrosion current in amps.

$\mathrm{R}_{\mathrm{P}}$ : the polarization resistance.

$\beta_{\mathrm{a}}$ : the anodic Beta Tafel constant in volts/decade.

$\beta_{\mathrm{c}}$ : the cathodic Beta Tafel constant in volts/decade.

In a polarization resistance experiment, a current versus voltage curve was recorded as the cell voltage was swept over a small range of potential that is very near to $\pm 10 \mathrm{mV}$. Also the Beta coefficient can be obtained from a Tafel plot.

According to ASTM Standard G102 ${ }^{11)}$, the standard practice for calculation of corrosion rates and related information from electrochemical measurements, the authors determined the corrosion rate using the following equation:

$$
C R=\frac{I_{\text {corr }} K E W}{d A}
$$

where

CR: the corrosion rate in milli-inches/year (mpy).

$\mathrm{I}_{\text {corr }}$ : the corrosion current in amps.

$\mathrm{K}$ : a constant that defines the units for the corrosion rate, $1.288 \times 10^{5}$ milli-inches/(amp-cm-year).

EW: the equivalent weight in grams/equivalent.

d: the density in grams $/ \mathrm{cm}^{3}$.

A: the sample area in $\mathrm{cm}^{2}$.

Normally, the working electrode (specimen to be tested) is a small button prepared, cleaned and polished

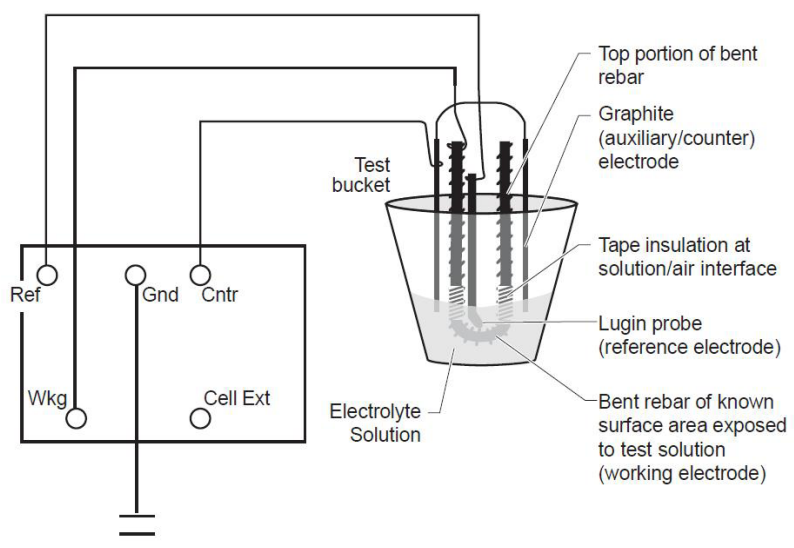

Fig.8. Schematic Diagram of Polarization Resistance Test Cell 


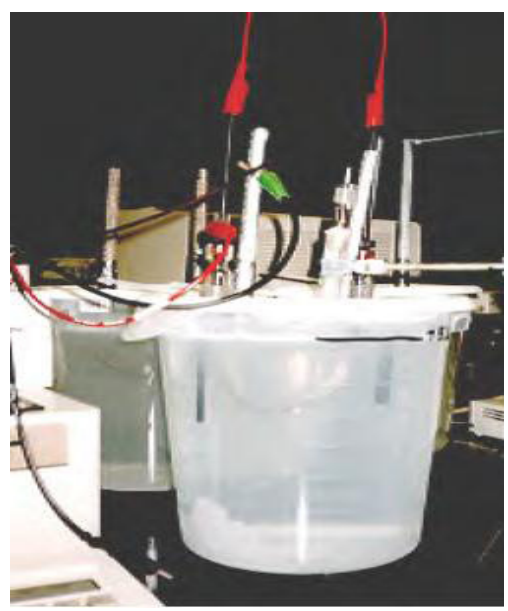

Fig.9. Polarization Resistance Test Cells with Connections

just one hour prior to experimentation. The entire polarization resistance test assembly is designed, keeping in mind the small button. However, in this research, the specimens or the working electrodes were bent \#4 bars. Hence, considerable changes had to be made to the test cell to fit the large working electrode. See Fig.8. for details.

The polarization tests, as shown in Fig.9., were conducted over a period of 6 days. Electrolytes were used for two days each. For the first two days, saturated calcium hydroxide solution was used $\left(1.85 \mathrm{gCa}(\mathrm{OH})_{2} /\right.$ liter of water). For the third and fourth days, an additional threshold amount of $\mathrm{NaCl}$ was added $(0.67 \mathrm{~g}$ $\mathrm{NaCl} /$ liter of water). For the fifth and sixth days, more $\mathrm{NaCl}$ was added to make the total amount of $\mathrm{NaCl}$ present in the test cell $3.5 \%$ (about $30 \mathrm{~g} \mathrm{NaCl} /$ liter of water). Calcium hydroxide was used as an electrolyte as it simulates the alkaline pore solution of concrete. A stable passivation layer was formed after two days of exposure to this electrolyte ${ }^{12}$. Sodium chloride solution was used to simulate the conditions of the real-life concrete structures exposed to deicing salts.

\section{Results and Discussion}

The test for four kinds of steel was performed and the results of the polarization resistance are shown in Table 2. and Fig.10.

As shown in Table 2., the salt concentration had three values: $0,0.011,0.513 \mathrm{~mol} / \mathrm{L}$. At value 0 , the environment had a $\mathrm{pH}$ value of about 12.7 , which simulated the alkaline pore solution of concrete. When the salt concentration was increased from $0.011 \mathrm{~mol} /$
$\mathrm{L}$ to $0.513 \mathrm{~mol} / \mathrm{L}$, it not only meant chloride ions appeared but also simulated the conditions of the real life concrete structures exposed to deicing salts ${ }^{12)}$.

In Fig.10., when the salt concentration was increased from 0 to $0.011 \mathrm{~mol} / \mathrm{L}$, the resistance of the black rebar decreased $90 \%$ while in contrast SS304, Galv. A and Galv. B increased 50\% for SS304, 432.5\% for Galv A and $145.9 \%$ for Galv B. In the first stage, while the resistance value of the black rebar decreased the others increased. The resistance value change meant that there was a metabolism between the environment and the steel. For the black rebar, this process occurred in a negative way, which corresponds with the corroded steel. In contrast, the other rebars were different. The process was delayed, meaning that some layers or barriers prevented corrosion.

The decrease of black rebar resistance continued when $0.502 \mathrm{~mol} / \mathrm{L}$ salt concentration was added. This phenomenon is the same with SS304, Galv. A and Galv. B. At the value $0.513 \mathrm{~mol} / \mathrm{L}$ of salt concentration, the SS304 had the highest resistance value of 51.77 (k-ohm $\mathrm{cm}^{2}$ ) and the black rebar had the lowest resistance value $3.182\left(\mathrm{k}-\mathrm{ohm} \mathrm{cm}^{2}\right)$. In the second stage, four of them had the same reaction with the environment. At that time, the process of the black rebar in the first stage occurred in the others, which meant that all of them were corroded.

The test results of the corrosion rate are shown in Table 3. and Fig.11. In Table 3., the corrosion rate was calculated by using equation 2 based on the results in Table 2.

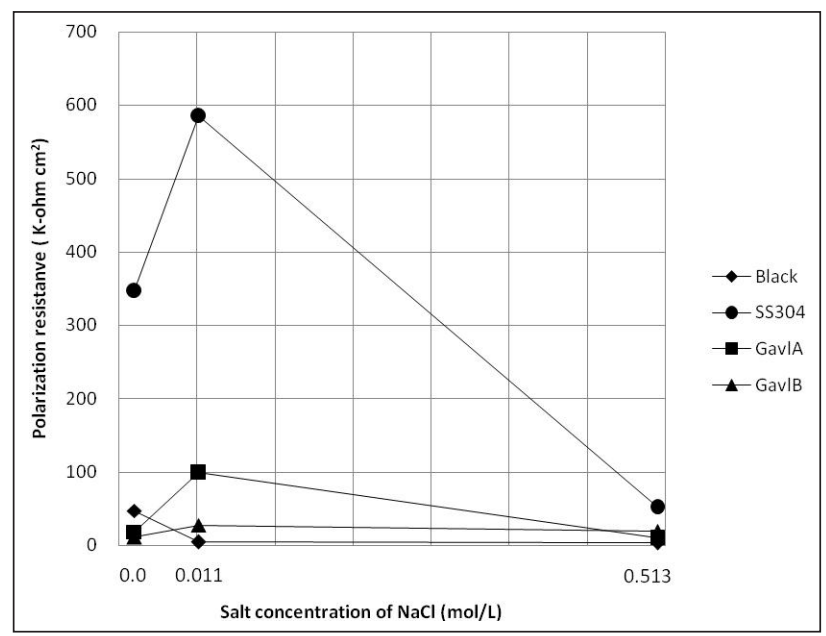

Fig.10. Relationship between Polarization Resistance and Salt Concentration of $\mathrm{NaCl}$

Table 2. Data of Relationship between Polarization Resistance and Salt Concentration

\begin{tabular}{ccccc}
\hline $\begin{array}{c}\text { Salt } \\
\text { concentration } \\
(\mathbf{m o l} / \mathbf{L})\end{array}$ & $\begin{array}{c}\text { Corrosion rate } \\
(\mathbf{m p y})\end{array}$ & $\begin{array}{c}\text { Corrosion rate } \\
(\mathbf{m p y})\end{array}$ & $\begin{array}{c}\text { Corrosion rate } \\
(\mathbf{m p y})\end{array}$ & $\begin{array}{c}\text { Corrosion rate } \\
(\mathbf{m p y})\end{array}$ \\
\hline & Black rebar & Pure SS304 rebar & Galv A coated rebar & Galv B coated rebar \\
\hline 0 & 0.190 & 0.026 & 0.698 & 1.150 \\
\hline 0.011 & 1.790 & 0.015 & 0.131 & 0.468 \\
\hline 0.513 & 3.150 & 0.174 & 1.300 & 0.652 \\
\hline
\end{tabular}




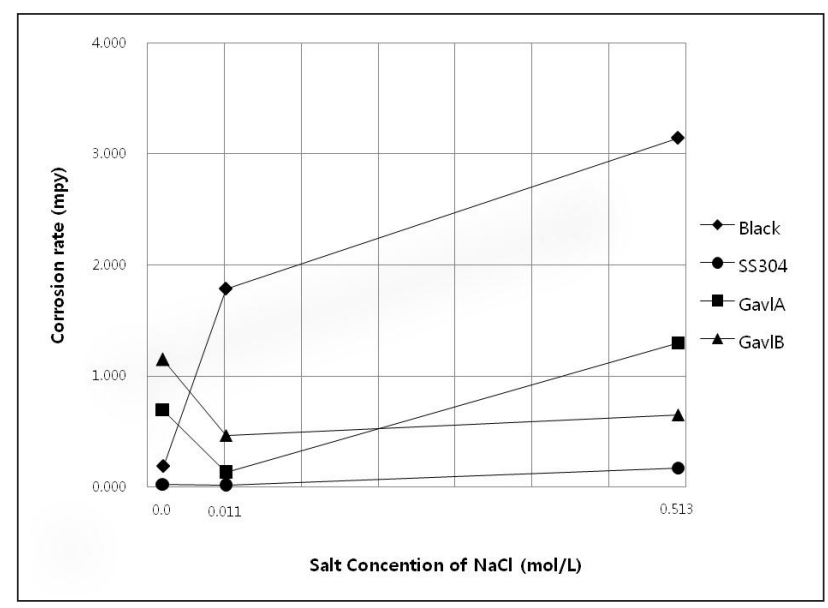

Fig.11. Relationship between Corrosion Rate and Salt Concentration of $\mathrm{NaCl}$

There are two parts in Fig.11. First, when the salt concentration increases from 0 to $0.011 \mathrm{~mol} / \mathrm{L}$ the corrosion rate of the black rebar is different from the others. It was increased about 9 times while the others were decreased 1.7 times for SS304, 5.3 times for Galv. A and 2.4 for Galv. B. However, when 0.502 $\mathrm{mol} / \mathrm{L}$ salt concentration was added, all of the rebars had the same reaction that increased the corrosion rate. At the value $0.513 \mathrm{~mol} / \mathrm{L}$ of salt concentration, black rebar was corroded a lot at 3.15 (mpy), while the others were lower than 1.5 (mpy).

At the value $0 \mathrm{~mol} / \mathrm{L}$ of salt concentration, the Galv. A rebar was corroded less than the Galv. B rebar. The reason is that Galv. B was coated after it was bent, while Galv. A was bent after it was coated.

Secondly, the Galv. A rebar was bent by the supplier at a more stringent bent diameter than the other rebars included in this study.

When the salt concentration is changed from 0 to $0.011 \mathrm{~mol} / \mathrm{L}$, the chloride ions appear in the enviroment, and will combine with the elements of the steel. With the black rebar, the main component is Fe, so it has these chemical reactions :

$$
\mathrm{Fe} \text { (solid) }-2 \mathrm{e} \rightarrow \mathrm{Fe}^{2+} \text { (ions) }
$$

Since the reaction releases electrons, they combine with the oxygen :

$$
\mathrm{O}_{2}+2 \mathrm{H}_{2} \mathrm{O}+4 \mathrm{e} \rightarrow 4 \mathrm{OH}^{-}
$$

Hence, we can see that oxygen $\left(\mathrm{O}_{2}\right)$ and water $\left(\mathrm{H}_{2} \mathrm{O}\right)$ are required to sustain the cathodic reaction of the overall corrosion process. When the concrete is dry, the oxygen diffuses and reaches the steel and when the concrete is wet, moisture is able to reach the steel. Thus the exposure conditions are an important aspect influencing reinforcement corrosion.

The role of chloride is unique. It can be reused repeatedly and subsequently even a small amount of chloride can sustain the corrosion process ${ }^{13)}$.

$$
\begin{gathered}
\mathrm{Fe}^{2+}+\mathrm{Cl}^{-} \rightarrow \mathrm{FeCl}_{2} \\
\mathrm{FeCl}_{2}+2 \mathrm{H}_{2} \mathrm{O} \rightarrow \mathrm{Fe}(\mathrm{OH})_{2}+2 \mathrm{Cl}^{-} \\
6 \mathrm{FeCl}_{2}+\mathrm{O}_{2}+6 \mathrm{H}_{2} \mathrm{O} \rightarrow 2 \mathrm{Fe}_{3} \mathrm{O}_{4}+12 \mathrm{H}^{+}+12 \mathrm{Cl}^{-}
\end{gathered}
$$

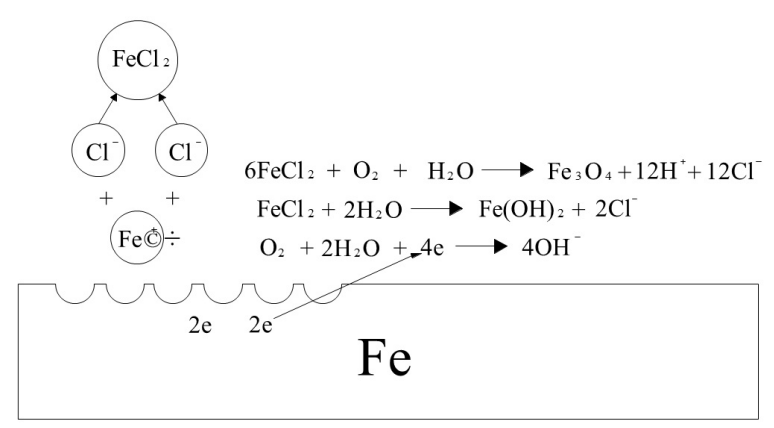

Fig.12. Corrosion Mechanism of Steel

Thus, the iron chloride reaction is self - perpetuating and the free chloride acts as a reaction catalyst.

Special rebars such as stainless steel or the galvanized coated rebar have quite different reactions from black rebar because their components have other elements besides $\mathrm{Fe}$ such as chromium, nickel (stainless steel), zinc (galvanized coated rebar).

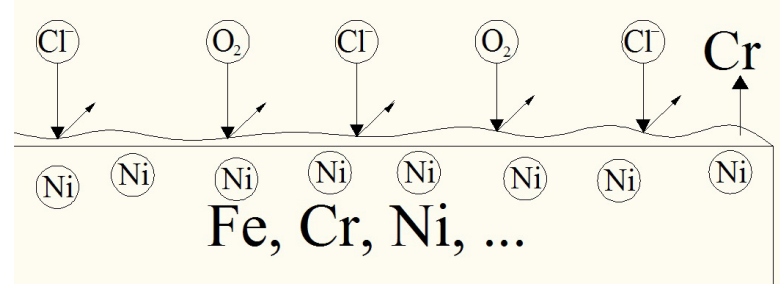

Fig.13. Role of Chrome and Nickel for Stainless Steel

For stainless steel, chromium is passivated by oxygen, forming a thin protective oxide surface layer.

Table 3. Data of Relationship between Corrosion Rate and Salt Concentration

\begin{tabular}{ccccc}
\hline $\begin{array}{c}\text { Salt } \\
\text { concentration } \\
(\mathbf{m o l} / \mathbf{L})\end{array}$ & $\begin{array}{c}\text { Corrosion rate } \\
(\mathbf{m p y})\end{array}$ & $\begin{array}{c}\text { Corrosion rate } \\
(\mathbf{m p y})\end{array}$ & $\begin{array}{c}\text { Corrosion rate } \\
(\mathbf{m p y})\end{array}$ & $\begin{array}{c}\text { Corrosion rate } \\
(\mathbf{m p y})\end{array}$ \\
\hline & Black rebar & Pure SS304 rebar & Galv A coated rebar & Galv B coated rebar \\
\hline 0 & 0.190 & 0.026 & 0.698 & 1.150 \\
\hline 0.011 & 1.790 & 0.015 & 0.131 & 0.468 \\
\hline 0.513 & 3.150 & 0.174 & 1.300 & 0.652 \\
\hline
\end{tabular}


This layer is a spinel structure only a few atoms thick. It is very dense, and prevents the diffusion of oxygen and the endosmosis of chloride ions into the underlying material. Nickel is also an important element that acts as a barrier to help the steel resist corrosion.

For the galvanized coated rebar, the process of prevention appears similar to stainless steel but in fact quite different. First, zinc combines with oxygen:

$$
2 \mathrm{Zn}+\mathrm{O}_{2} \rightarrow 2 \mathrm{ZnO}
$$

Zinc oxide is nearly insoluble in water, it becomes the layer around the steel preventing the endosmosis of water and chloride ions. When chloride ions overcome this layer they combine with zinc :

$$
\mathrm{Zn}^{2+}+2 \mathrm{Cl}^{-} \rightarrow \mathrm{ZnCl}_{2}
$$

$\mathrm{ZnCl}_{2}$ is a passive layer, and has the same role as $\mathrm{ZnO}$, meaning that it prevents corrosion from the environment.

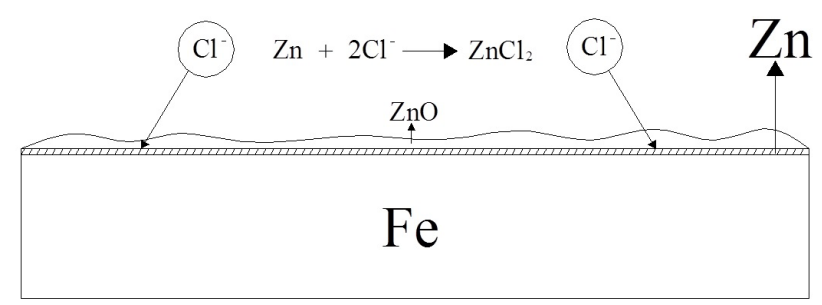

Fig.14. Role of $\mathrm{ZnCl}_{2}$ in Protecting Corrosion

The aforementioned reasons explain why the polarization resistance was increased with 0 to 0.011 $\mathrm{mol} / \mathrm{L}$ of salt concentration.

When more $0.502 \mathrm{~mol} / \mathrm{L}$ concentration is added, the reaction of the four specimens is exactly the same. All polarization resistance values were reduced. This means that chloride ions have already overcome every barrier to meet Fe. Chloride ions have a successful endosmosis into the barrier, which makes the protective layer inactive. At that time the stainless steel and galvanized coated rebar will have the same reaction as the black rebar:

$$
\begin{gathered}
\mathrm{Fe}^{2+}+\mathrm{Cl}^{-} \rightarrow \mathrm{FeCl}_{2} \\
\mathrm{FeCl}_{2}+2 \mathrm{H}_{2} \mathrm{O} \rightarrow \mathrm{Fe}(\mathrm{OH})_{2}+2 \mathrm{Cl}^{-} \\
6 \mathrm{FeCl}_{2}+\mathrm{O}_{2}+6 \mathrm{H}_{2} \mathrm{O} \rightarrow 2 \mathrm{Fe}_{3} \mathrm{O}_{4}+12 \mathrm{H}^{+}+12 \mathrm{Cl}^{-}
\end{gathered}
$$

Through simulation studies, Hausmann in $1967^{14)}$ showed that the initiation of corrosion requires a ratio of chloride to hydroxyl ion activity of at least 0.6 . At the value $0.011 \mathrm{~mol} / \mathrm{L}$ of salt concentration, the ratio of chloride to hydroxyl ion is equal to 0.229 . This is lower than 6, and there is no corrosion in SS304 and the galvanized coated rebar. However, this is not the case for the black rebar, which is corroded. At the value $0.513 \mathrm{~mol} / \mathrm{L}$ of salt concentration, the ratio of chloride to hydroxyl ion is equal to 10.5 . It is greater than 6 and all of the rebar is corroded.

\section{Conclusion}

The polarization resistance test gives valuable qualitative information on the nature of corrosion in reinforcements. The following conclusions have been drawn:

The S304 rebar, galvanized A rebar and galvanized $B$ rebar were corroded less than 1.5 mpy in $\mathrm{Ca}(\mathrm{OH})_{2}$ plus $3.5 \% \mathrm{NaCl}$. The SS304 rebar is the most effective in all three solutions; it has extremely low corrosion rates.

The black steel was corroded much more than others with the presence of salt. However, its corrosion rate was less than that of both galvanized A and galvanized $B$ rebars in pure calcium hydroxide solution. Its corrosion rate was dramatically increased in the presence of salt.

The galvanized A rebar performed better than galvanized $\mathrm{B}$ rebar in pure calcium hydroxide solution as well as in $\mathrm{Ca}(\mathrm{OH})_{2}+$ the threshold amount $\mathrm{NaCl}$. However, galvanized B performed better in the presence of $3.5 \% \mathrm{NaCl}$.

\section{Acknowledgement}

This research was supported by the MKE (The Ministry of Knowledge Economy), Korea, under the Convergence -ITRC (Convergence Information Technology Research Center) supervised by the NIPA (National IT Industry Promotion Agency) (NIPA2011-C6150-1101-0003) and a grant (code\# 20090087819, 2010-0019373 and 2011-0010300) from the National Research Foundation of Korea (NRF) funded by the Korea government.

\section{References}

1) http://en.wikipedia.org/wiki/Rebar.

2) http://www.gewater.com/handbook/boiler_water_systems/fig1415.jsp.

3) http://www.galvanizedrebar.com/galvanizing_process.htm.

4) http://www.galvanizeit.org/images/uploads/publicationPDFs/ Z-ZC-06.pdf.

5) Newson T., (2001) Stainless steel-applications, grades and human exposure, AvestaPolarit Oyj Abp.

6) http://www.stainless-online.com/why-stainless-steel-stainless.htm.

7) http://en.wikipedia.org/wiki/Stainless_steel.

8) http://www.georgesbasement.com/Microstructures/Unknowns/ Iron-Based/Specimen08.htm.

9) Redaelli E., Bertolini L., Peelen W. and Polder R. (2006) FEM-models for the propagation period of chloride induced reinforcement corrosion, Materials and Corrosion, 57 (8), pp.28635.

10) http://www.gamry.com/App_Notes/DC_Corrosion/GettingStarted WithEchemCorrMeasurements.htm. 
11) ASTM Standard G102, Standard practice for calculation of corrosion rates and related information from electrochemical measurements.

12) Elsener B., Buchler M., Stalder F., and Bohni H. (1991) Migrating Corrosion Inhibitor Blend for Reinforced Concrete: Part 1-Prevention of Corrosion, The Journal of Corrosion Science and Engineering, 55 (12), pp.1155-1163.

13) Thangavel K., Rengaswamy N.S. (1998) Relationship between chloride/hydroxide ratio and corrosion rate of steel in concrete, Cement and Concrete Composites, 20, pp.283-292.

14) Hausmann D.A. (1967) Steel corrosion in concrete. How does it occur?, Materials protection, 6, pp.19-23. 